Contents lists available at Journal Redwhitepress
Journal of Educational and Learning Studies
ISSN: 2655-2760 (Print) ISSN: 2655-2779 (Electronic)
Journal homepage: http://journal.redwhitepress.com/index.php/iles

\title{
The Contribution of Adversity Quotient to Learning Outcomes of Students in Middle School and the Counseling Services Implication
}

\author{
Shelly Fadhila ${ }^{1}$, Mudjiran $^{1}$, Nurhizrah Gistituati ${ }^{1}$ \\ ${ }^{1}$ Universitas Negeri Padang
}

\begin{tabular}{l}
\hline Article Info \\
\hline Article history: \\
Received Mei $24^{\text {th }}, 2019$ \\
Revised Jul $16^{\text {th }}, 2019$ \\
Accepted Aug $14^{\text {th }}, 2019$ \\
\hline
\end{tabular}

\section{Keyword:}

First keyword

Second keyword

Third keyword

Fourth keyword

Fifth keyword

\section{Corresponding Author:}

Shelly Fadhila

Universitas Negeri Padang

Email: shellyfadhila34@gmail.com

\begin{abstract}
Some aspects that are thought to be factors that cause success or failure of students in obtaining good learning outcomes are the ability of students to deal with and solve problems they experience (adversity quotient). The purpose of this study was to look at the effect of adversity quotient (AQ) on student learning outcomes of students and their implications in guidance and counseling services. Based on the results of the study it was found that adversity quotient give contributed to student learning outcomes. The implications of the results of this study can be used as an analysis of the needs of students in the preparation of Guidance and Counseling service programs in schools, especially Muhammadiyah Middle School in Padang.
\end{abstract}

(C) 2019 The Authors. Published by Redwhitepress.

This is an open access article under the CC BY-NC-SA license (https://creativecommons.org/licenses/by-nc-sa/4.0/

\section{Introduction}

Each individual experiences a learning process in life to make changes in him in the form of mastering certain skills, changing attitudes, having new knowledge (Mulyani, 2017). H acyl learn is an indicator of quality and knowledge possessed by students after participating in the learning process through which learning outcomes can be somewhat controlled by the student's knowledge (David, 2012). Learning outcomes are behaviors possessed by students from learning processes that are cognitive, affective, and psychomotor (Fernanda, Sano, \& Nurfarhanah, 2017). When carrying out individual learning activities always expect for can get good learning results. However, it is not uncommon for behavioral changes that are expected to not be fully achieved through the learning process, so that educational goals have not been achieved as expected. Success or failure of learning depends on how the learning process is experienced by students. Because learning outcomes are influenced by many factors, namely internal factors, external factors, and instrument factors (Aritonang, 2008). The more factors that support learning activities, the greater the likelihood of the expected behavior change process occurring. Conversely, the more factors that do not support learning activities, the smaller the likelihood of the expected process of change in behavior will be reduced.

Based on data obtained from the Ministry of Education and Culture of the Republic of Indonesia, it is known that for the basic data of West Sumatra Province Middle School education that in 2016/2017 from 216,200 students there were 1,512 students who repeated and 709 students dropped out of school the study group was 8,111 students (Ministry of Education and Culture, 2017). From these data, it can be seen that at the junior high school level not all students are able to achieve learning outcomes as expected, marked by the 
number of students who have to repeat in the same class and the number of students who drop out of school. This is evidence that even though learning has been prepared by the school as best as possible with all its facilities, it is not enough to support the achievement of good learning outcomes for all students. Because of many things and other factors that can affect students and their learning outcomes.

The learning process that is followed by students is not always static, but is dynamic and colored by various problems, both those originating from within themselves and originating from their environment. The success of students in the learning process is determined by how students overcome the difficulties that occur (Supardi, 2013). So that to achieve good learning outcomes, it takes sincerity and endurance in dealing with problems and risks to the business. One aspect that is thought to be a factor in the success or failure of students in obtaining good learning outcomes is the ability of students to deal with and solve problems they experience, which in psychology is better known as adversity quotient (Stoltz, 2004).

Adversity quotient is someone's intelligence to overcome the difficulties that occur in his life (Kusumawati, 2017). Adversity quotient is students' persistence in dealing with and overcoming every difficulty that occurs during the learning process (Ahmad, 2016). So that adversity quotient is often identified as a fighting force in fighting difficulties (Hidayat \& Sariningsih, 2018). Deeper, adversity quotient is defined as the ability to think, manage, direct, and endure a person against challenges and difficulties in achieving success (Utami, Hardjono, \& Karyanta, 2014). Furthermore, adversity quotient is considered to predict performance, perseverance, endurance, and response to change so that adversity quotient plays an important role in one's life and career (Tian \& Fan, 2014). Based on some of these explanations, it can be seen that adversity quotient underlies all aspects of success, including in one's career and life.

Stoltz (2004), explains that adversity quotient is the ability that a person has in observing difficulties and processing these difficulties with intelligence that is owned so that it becomes a challenge to solve. Someone who has a high adversity quotient will be able to enjoy greater productivity, performance, vitality, tenacity, health, knowledge, improvement, motivation and success by continuing to struggle in facing problems that arise and have the desire to develop as a form of self-actualization (Ahyani, 2016). By having a high adversity intelligence someone will be able to overcome obstacles or problems that arise in his life, not regardless of the problems experienced by students in school. Conversely someone who has a low adversity quotient will feel helpless, easy to give up and pessimistic when facing various obstacles or other forms of misery. Such an attitude is clearly not a success (Stoltz, 2004).

The results of the interview with the BK Muhammadiyah 5 SMP guidance and counseling teacher on Thursday, July 5, 2018, it is known that out of all the students there were about $20 \%$ of all students coming from broken home families and experiencing problems with the learning outcomes they obtained. Then most students who are often late and absent from school also come from families with a middle to lower economy. Furthermore, many of the students are affected by the negative behavior of other students, thus affecting the learning process. This gives the meaning that many students in Muhammadiyah Middle School 5 Padang have not been able to overcome the problems that arise in the learning process that they do.

One of the results of the study found that students who had high adversity quotient, their learning outcomes were better than students with low adversity quotient. This can be seen in the low adversity quotient, the average value obtained by students is 70.45 and the high adversity quotient is 90.45 (Herawati Nyoman Trisna, 2013) . In addition, research conducted on Malaysian polytechnic students as many as 1,845 students shows that adversity quotient contributes as much as $9 \%$ changes to student academic achievement scores (Effendi, Mohd, Khairani, \& Razak, 2015).

Based on the description above, the author views the need for in-depth study of learning outcomes related to student adversity quotient (AQ) and its implications in guidance and counseling services. Thus, the counselor/counselor plays an important role in helping alleviate the problems faced by students. Therefore, the counselor/counselor should play an active role in helping to improve student learning outcomes by using various types of services and supporting activities to achieve satisfying student learning outcomes.

\section{Method}

This study uses a quantitative approach with descriptive methods. The study was conducted on Muhammadiyah 5 Junior High School students in Padang, West Sumatra, Indonesia. The sample in this study were 200 students of class VII and VIII selected by the Proportional Stratified Random Sampling technique. The instrument used was an adversity quotient questionnaire which was developed using a Likert scale model consisting of 34 items with reliability of 0.847 ( Cronbach Alpha ). For student learning outcomes taken from the value of the midterm test 2 . 
The Contribution of Adversity Quotient to Learning Outcomes of Students in Middle School and the Counseling Services Implication

\section{Results and Discussion}

\section{Data Description}

The data in this study include adversity quotient (X 1 ) and degree (Y) variables. The following is a description of the research data. Based on the results of the study it can be seen that no student who has a very high adversity quotient, some students are in the high category that is equal to $3 \%$, students are in the moderate category at $29 \%$, then in the low category at $58.5 \%$, and in the very low category at $9.5 \%$. So, overall the adversity quotient of students is in a low category. Based on the results of the study it can be seen that no student who has a very high learning outcomes, the students who have learning outcomes in higher category that is equal to $6 \%$, most of the other students in middle category that is equal to $39.5 \%$, then in the low category of $46.5 \%$, and in the very low category at $8 \%$. So, overall student learning outcomes are in the medium category.

The results of the analysis of the contribution of adversity quotient to learning outcomes the $r$ value is 0.469 which shows the regression coefficient of adversity quotient on learning outcomes. Then, the $\mathrm{r}$ squared value of 0.220 means that adversity quotient contributes to learning outcomes by $22 \%$ while $78 \%$, is influenced by other factors.

\section{Discussion}

\section{Adversity Quotient}

The results of the research data analysis show that on average the overall students of Padang 5 Muhammadiyah Middle School have a low adversity quotient. In other words, most students are not able to overcome obstacles or problems that occur in their lives well, as well as the problems experienced by students in school. Adversity Quotient is a very important aspect that must be for each individual to be able to achieve a goal. Terminologically, adversity quotient is the ability of a person to struggle in facing and overcoming difficulties, and changing these difficulties into opportunities for greater achievement (Effendi, Mohd, \& Khairani, 2016). Adversity quotient gives an idea of how much a person can endure difficulties and the ability to overcome these difficulties (Haryanto, 2010). In the learning process, students will always meet obstacles and obstacles. Furthermore, it is also explained that adversity quotient is the ability of an individual to survive in facing all kinds of problems to find a way out, solve various problems, reduce obstacles and obstacles by changing the way of thinking and attitudes towards the difficulties encountered (Septiana, 2015) . In an educational perspective, adversity quotient is the ability needed to continue to struggle when students face difficulties in the learning process to achieve satisfying learning outcomes (Effendi et al., 2016) . It can be seen that the potential of adversity quotient is needed by students in the learning process so that students get good learning outcomes.

Stoltz (2000) explains that adversity quotient is someone's intelligence in facing obstacles or difficulties regularly (Amelia, 2016). In other words, adversity quotient helps students strengthen their abilities and perseverance in facing challenges good daily life in the learning process while sticking to the principles and dreams regardless of the difficulties that are being experienced. Adversity quotient can be a behavior pattern to help adjust to circumstances and uncertainties that change quickly, no matter how difficult the problem or difficulty (Siphai, 2015) . Based on these opinions, it is known that adversity quotient is the ability of students to use their intelligence to direct, change the way they think and act when facing obstacles and difficulties during the learning process. So that students can overcome these difficulties and can rise from failure.

\section{Learning outcomes}

The results of descriptive data analysis show that from the whole subject, the learning outcomes of students of Padang 5 Muhammadiyah Middle School are in the medium category. From the results of research that researchers have done, it appears that the acquisition of student learning outcomes is still far from ideal learning outcomes. According to Prayitno, ideal learning outcomes are if students are able to masterfully (90$100 \%)$ all subject matter with various demands which include elements of the cognitive, affective and psychomotor domains (Putri, Nirwana, \& Syahniar, 2019). The learning outcomes are student achievements that can be measured from the values obtained by students after carrying out evaluations. (Siagian, 2012). So that learning outcomes are the final assessment of the process and the introduction that has been done repeatedly and stored for a long time, both in the form of numbers and behavior (Sjukur, 2018) . Learning outcomes are the level of success achieved by students after participating in a learning activity where the level of success is marked by the scale of values in the form of letters, numbers or symbols (Dimiyati \& Mudjiono, 2009). Based on some of these explanations, it can be concluded that after going through the learning process, students can obtain information and knowledge that causes changes in behavior in the individual concerned 
because of the practice and experience. Grouping student learning outcomes are grouped based on their completeness in mastering subject matter. Thus learning outcomes are grouped into complete learning and incomplete learning. Sumiati \& Asra (2013) suggest that what is meant by complete learning is mastery (learning outcomes) of students in full of all learning material learned. The completeness category is determined by the educator in the board of educator meetings that determine the KKM..

\section{Contribution of Adversity Quotient to Learning Outcomes and Their Implications in Guidance and Counseling}

The results of the study show that adversity quotient contributes significantly to learning outcomes. This finding was obtained based on a series of data analysis which showed that the contribution of adversity quotient to learning outcomes was $22 \%$. That is, adversity quotient is one of the factors that contribute to student learning outcomes. Referring to this study it is understood that the higher the adversity quotient of students, the higher the student learning outcomes. This means that the adversity quotient determines the acquisition of student learning outcomes. This is in accordance with the opinion of Stoltz (2004) that with a high level of adversity quotient, students will never provide opportunities for each difficulty and obstacle will affect their enthusiasm and effort in achieving goals, one of which is achieving satisfying learning outcomes. In line with that, Hamdani Bakran Adz Dzakiey (2006) also explained that adversity quotient is a potential which with that potential one can change the obstacles it faces into opportunities. He also added that the success of a job and a person's life is determined by its level of adversity quotient (Kusumawati, 2017).

Based on the results of research conducted on class VIII students at Dalopo MTsN explained that adversity quotient influences students' thinking processes in solving mathematical problems that certainly affect student learning outcomes so that in AQ learning students need to be considered (Masfingatin, 2012) . Furthermore, research conducted at Tugu Ibu 1 High School explained that there was a significant influence between adversity quotient and mathematics learning achievement. Students who have high adversity quotient will be able to resolve obstacles in front of them and achieve achievements in learning (Nurhayati \& Fajrianti, 2013). The results of the study were also conducted on class XI students of SMAN Integrated Model Madani Palu, explaining that adversity quotient had an influence on mathematics learning outcomes by $43.1 \%$. (Rukmana, Hasbi, \& Paloloang, 2016) . Furthermore, the researchers also found that students' AQ in learning had an influence on mathematical learning outcomes because in learning mathematics students were required to be able to solve mathematical problems related to life. If students have high AQ in learning, especially in mathematics, students will continue to do more business because students who have high AQ will also have high learning motivation. This is what will lead students to better and more satisfying achievement or learning outcomes (Rukmana et al., 2016).

Based on the explanation above, it can be understood that adversity quotient has an influence on student learning outcomes. The higher the adversity quotient possessed by students, the higher the learning outcomes that students will get. So, to improve student learning outcomes, one of them is by increasing students' adversity quotient.

In this study students' adversity quotient in the low category. Therefore, BK teachers need to help students improve their adversity quotient so that students can follow the learning process optimally to improve student learning outcomes. There are several services that can be implemented to improve the adversity quotient of students including information services, content mastery services and group guidance services. Information services, such as providing information services about the importance of adversity quotient in life. Content mastery services, such as providing ways or tips to improve adversity quotient in yourself. Group guidance services with assignment topics, such as the importance of recognizing and increasing adversity quotient within oneself.

\section{Conclusion}

Based on the findings and discussion of the results of the research, the following conclusions can be put forward:

1. The description of the adversity quotient of students of Padang Muhammadiyah Middle School 5 is in a low category.

2. The description of the learning outcomes of students in Padang 5 Muhammadiyah Middle School is in the medium category.

3. Adversity quotient of students of Padang Muhammadiyah 5 Middle School contributed significantly to learning outcomes which were equal to $22 \%$. That is, if the student's adversity quotient improved to 
be higher, then the learning outcomes will improve for the better, or vice versa if the adversity quotient is students low, it will result in decreased learning outcomes.

The results of this study may be used as input for guidance and counseling teachers in the preparation of guidance and counseling service programs in schools related to material that is in accordance with the conditions and needs of students. So that through guidance and counseling services, counselors can help students improve adversity quotient, so that students are able to follow the learning process optimally to get good learning outcomes.

\section{References}

Ahmad, R. S. (2016). Pengaruh Math Phobia, Self Efficacy, Adversity Quotient dan Motivasi Berprestasi terhadap Prestasi Belajar Matematika Siswa SMP, 3(2), $259-272$. https://doi.org/http://dx.doi.org/10.21831/jrpm.v3i2.6138

Ahyani, L. N. (2016). Meningkatkan Adversity Quotient (Daya Juang) Pada Anak Anak Panti Asuhan Melalui Penguatan Sosial Support, 53-61.

Amelia, M. (2016). Pengaruh Adversity Quotient, Iklim Kelas, dan Kebiasaan Belajar terhadap Prestasi Belajar Ekonomi Siswa Kelas XI.IS SMA Negeri Di Kabupaten Tanah Datar, 4(1). https://doi.org/http://dx.doi.org/xx.Xxxx/economica.2012.355 Abstract

Aritonang, K. (2008). Minat dan Motivasi dalam Meningkatkan Hasil Belajar Siswa. Jurnal Pendidikan Penabur, (10), 11-21. https://doi.org/10.1017/CBO9781107415324.004

Daud, F. (2012). Pengaruh Kecerdasan Emosional (EQ) dan Motivasi Belajar terhadap Hasil Belajar Biologi Siswa SMA 3 Negeri Kota Palopo. Jurnal Pendidikan Dan Pembelajaran (JPP), 19(2), $243-255$. https://doi.org/10.1287/moor.2013.0633

Dimiyati \& Mudjiono. (2009). Belajar dan Pembelajaran. Jakarta: Rineka Cipta.

Effendi, M., Mohd, E., \& Khairani, A. Z. (2016). Correlation between Adversity Quotient ( AQ ) with IQ , EQ and SQ Among Polytechnic Students Using Rasch Model, 9. https://doi.org/10.17485/ijst/2016/v9i47/108695

Effendi, M., Mohd, E., Khairani, A. Z., \& Razak, N. A. (2015). The Influence of AQ on the Academic Achievement among Malaysian Polytechnic Students, 8(6), 69-74. https://doi.org/10.5539/ies.v8n6p69

Fernanda, M. M., Sano, A., \& Nurfarhanah, . (2017). Hubungan antara Kemampuan Berinteraksi Sosial dengan Hasil Belajar. Konselor, 1(2), 1-8. https://doi.org/10.24036/0201212698-0-00

Herawati Nyoman Trisna. (2013). Pengaruh Pemanfaatan Intermedia Dan Adversity Quotient Terhadap Hasil Belajar Akuntansi Pengantar I, 3.

Hidayat, W., \& Sariningsih, R. (2018). Kemampuan Pemecahan Masalah Matematis dan Adversity Quotient Siswa SMP Melalui Pembelajaran Open Ended, 2(1), 109-118.

Kementerian Pendidikan dan Kebudayaan. (2017). Ikhtisar Data Pendidikan Tahun 2016/2017.

Kusumawati, E. D. (2017). Pengaruh Adversity Quotient terhadap Regulasi Diri Siswa Kelas Khusus Olahraga ( KKO ) SMP Negeri 13 Yogyakarta. Jurnal Pendidikan Madrasah, 2(1), 121-141. https://doi.org/10.14421/jpai.2017.141-08

Masfingatin, T. (2012). Proses Berpikir Siswa Sekolah Menengah Pertama dalam Memecahkan Masalah Matematika Ditinjau dari Adversity Quotient.

Mulyani, D. (2017). Hubungan Kesiapan Belajar Siswa Dengan Prestasi Belajar. Konselor, 2(1), $27-31$. https://doi.org/10.24036/0201321729-0-00

Nurhayati, N., \& Fajrianti, N. (2013). Pengaruh Adversity Quotient (AQ) dan Motivasi Berprestasi terhadap Prestasi Belajar Matematika. Jurnal Formatif, 3(1), https://doi.org/http://dx.doi.org/10.30998/formatif.v3i1.110

Putri, N. E., Nirwana, H., \& Syahniar. (2019). Hubungan kondisi lingkungan keluarga dengan hasil belajar siswa sekolah menengah atas, 3(2018), 98-102.

Rukmana, I., Hasbi, M., \& Paloloang, B. (2016). Hubungan Adversity Quotient dengan Hasil Belajar Matematika Siswa Kelas XI SMA Negeri Model Terpadu Madani Palu. Jurnal Elektronik Pendidikan 
Matematika Tadulako, 03.

Septiana, A. (2015). Contextual Teaching And Learning Approach (CTL) In Mathematics To Develop Adversity Quotient (AQ), (May), 17-19.

Siagian, R. E. F. (2012). Pengaruh Minat dan Kebiasaan Belajar Siswa terhadap Prestasi Belajar Matematika. Formatif: Jurnal Ilmiah Pendidikan MIPA, 2(20), 122-131. https://doi.org/http://journal.lppmunindra.ac.id/index.php/Formatif/article/viewFile/750/659

Siphai, S. (2015). Influences of Moral , Emotional and Adversity Quotient on Good Citizenship of Rajabhat University, $\mathrm{s}$ Students in the Northeast of Thailand, 10(17), 2413-2421. https://doi.org/10.5897/ERR2015.2212

Sjukur, S. B. (2018). Pengaruh blended learning terhadap motivasi belajar dan hasil belajar siswa di tingkat SMK. Jurnal Pendidikan Vokasi, 2(3), 368-378. https://doi.org/10.21831/jpv.v2i3.1043

Stoltz, P. G. (2004). Adversity Quotient: Mengubah Hambatan Menjadi Peluang. (Terj. T. Hermaya; Ed. Yovita Hardiwati). (Cetakan Kelima. Jakarta:PT Grasindo.

Sumiati dan Asra. (2013). Metode Pembelajaran. Bandung: Wacana Prima.

Supardi. (2013). Pengaruh Adversity Quotient terhadap Prestasi Belajar Matematika, 3(1), 61-71.

Tian, Y., \& Fan, X. (2014). Adversity quotients, environmental variables and career adaptability in student nurses. Journal of Vocational Behavior, 85(3), 251-257. https://doi.org/10.1016/j.jvb.2014.07.006

Utami, I. bekti, Hardjono, \& Karyanta, N. A. (2014). Hubungan antara optimisme dengan adversity quotient pada mahasiswa Program Studi Psikologi Fakultas Kedokteran UNS yang mengerjakan skripsi. Jurnal Ilmiah Psikologi Candrajiwa, 2(5), 154-167. 